\title{
Hematological values associated to the serological and molecular diagnostic in cats suspected of Ehrlichia canis infection
}

\author{
Valores hematológicos associados ao diagnóstico sorológico e molecular \\ de gatos suspeitos de infecção por Ehrlichia canis
}

Ísis Assis Braga ${ }^{1,2}$; Luana Gabriela Ferreira dos Santos²; Andréia Lima Tomé Melo'; Felipe Wolf Jaune;

Thaysa Felfili Ziliani²; Ângela Ferronatto Girardi'; Daniel Moura de Aguiar ${ }^{2 *}$

\author{
${ }^{1}$ Programa de Pós-graduação em Ciências Veterinárias, Faculdade de Agronomia, Medicina Veterinária e Zootecnia, \\ Universidade Federal de Mato Grosso - UFMT, Cuiabá, MT, Brasil \\ ${ }^{2}$ Laboratório de Virologia e Rickettsioses, Hospital Veterinário, Universidade Federal de Mato Grosso - UFMT, Cuiabá, MT, Brasil \\ ${ }^{3}$ Laboratório de Patologia Clínica Veterinária, Hospital Veterinário, Universidade Federal de Mato Grosso - UFMT, Cuiabá, MT, Brasil
}

Received March 21, 2013

Accepted June 17, 2013

\begin{abstract}
The literature contains several studies on feline ehrlichiosis. However, information about the characteristics of Ehrlichia infection in cats is still scanty. This study evaluated the association between Ehrlichia spp. infection and the hematologic data of 93 cats treated at the Federal University of Mato Grosso Veterinary Hospital in Cuiabá, state of Mato Grosso, Brazil. The presence of or exposure to Ehrlichia spp. infection was evaluated by Polymerase Chain Reaction (PCR) targeting the $d s b$ and 16S rRNA gene of Ehrlichia, and by detection of anti-Ehrlichia canis IgG antibodies in Indirect Fluorescence Assay (IFA), respectively. Eight (8.6\%) cats tested positive by PCR and the partial DNA sequence obtained from PCR products was a $100 \%$ match to E. canis. Forty-two (45.1\%) cats showed antibody reactivity against Ehrlichia spp. Hematological alterations such as low erythrocyte count, thrombocytopenia, lymphopenia and monocytosis were observed in PCR positive cats. Among them, low erythrocyte counts were associated with IgG antibody titers of 40 to 640 and five cats also tested positive by PCR. Furthermore, PCR-positive cats showed a tendency to be lymphopenic. No correlation was found between age and sex, and no ticks were observed in any of the examined cats.
\end{abstract}

Keywords: Ehrlichiosis, feline, hematology, polymerase chain reaction, indirect fluorescence assay, diagnosis.

\section{Resumo}

Diversos estudos sobre erliquiose felina vêm sendo relatados na literatura. No entanto, a caracterização da infecção por Ehrlichia em gatos ainda é escassa. O presente estudo objetivou avaliar a associação entre infecção por Ehrlichia e dados hematológicos em 93 gatos atendidos no Hospital Veterinário da Universidade Federal de Mato Grosso, em Cuiabá, Brasil. A presença de infecção por Ehrlichia spp. foi avaliada pela Reação em Cadeia pela Polimerase (PCR) visando à amplificação dos genes dsb e $16 \mathrm{~S}$ rRNA de Ehrlichia e por Reação de Imunofluorescência Indireta (RIFI). Oito $(8,6 \%)$ gatos demonstraram ser positivos pela PCR, sendo suas sequências parciais de DNA $100 \%$ idênticas à E. canis. Quarenta e dois gatos $(45,1 \%)$ apresentaram anticorpos reativos contra Ehrlichia spp. Alteraçóes hematológicas como baixas contagens de eritrócitos, trombocitopenia, linfopenia e monocitose foram observadas em gatos positivos pela PCR. Dentre essas, eritropenia foi associada em gatos com títulos de anticorpos IgG entre 40 e 640, sendo cinco destes positivos pela PCR. Adicionalmente, gatos positivos na PCR apresentaram uma tendência a serem linfopênicos. Não foram observadas associaçôes entre a presença de infecção nos gatos e suas respectivas idades e sexo. Nenhum carrapato foi observado nos gatos examinados.

Palavras-chave: Erliquiose, felinos, hematologia, reação em cadeia pela Polimerase, reação de imunofluorescência indireta, diagnóstico.

\footnotetext{
${ }^{*}$ Corresponding author: Daniel Moura de Aguiar

Laboratório de Virologia e Rickettsioses, Hospital Veterinário, Universidade

Federal de Mato Grosso - UFMT, Av. Fernando Corrêa, 2367, Boa Esperança,

CEP 78060-900, Cuiabá, MT, Brasil

e-mail: danmoura@ufmt.br
} 


\section{Introduction}

Ehrlichiosis, which is caused by Ehrlichia canis, has been recognized as an important worldwide infectious disease, especially in dogs (VIEIRA et al., 2011). Symptoms suggestive of ehrlichiosis infection have also been reported in domestic cats in several countries. The Ehrlichia species that naturally infect cats have not yet been fully determined, although monocyte and lymphocyte inclusions and, more consistently, E. canis DNA, have been detected in cats (BREITSCHWERDT et al., 2002; OLIVEIRA et al., 2009; BRAGA et al., 2012), as well as some granulocytic inclusions related to feline granulocytic ehrlichiosis caused by Anaplasma phagocytophilum (BUORO et al., 1989; BOULOY et al., 1994; BEAUFILS et al., 1995; BJOERSDORFF et al., 1999; SHAW et al., 2001; AGUIRRE et al., 2004).

The growing number of cat breeders has increased the demand for veterinary care, and as a result, more studies on feline diseases are now being conducted (LITTLE, 2010). Feline ehrlichiosis has been investigated in order to understand its pathogenesis and to determine the characteristics of its pattern of infection (BUORO et al., 1989; BOULOY et al., 1994; BEAUFILS et al., 1995). Some reports of $E$. canis infection in cats have shown hematological alterations such as bone marrow hypoplasia or dysplasia, accompanied by pancytopenia or anemia and thrombocytopenia. Based on clinical and laboratory findings, the pathogenesis of the disease seems likely to be similar to Canine Monocytic Ehrlichiosis (CME) (BREITSCHWERDT et al., 2002; OLIVEIRA et al., 2009).

This study involved an evaluation of possible associations between Ehrlichia infection and hematologic data in cats treated at a Brazilian veterinary hospital. The presence of or exposure to E. canis was determined by Polymerase Chain Reaction (PCR) and by detection of anti-E. canis $\operatorname{IgG}$ antibodies by Indirect Fluorescence Assay (IFA), respectively.

\section{Materials and Methods}

\section{Study site and blood collection}

A total of 93 domestic cats were selected randomly from May 2011 to December 2011 and subjected to veterinary examinations for several reasons at a veterinary hospital in Cuiabá, a city located in the midwestern region of Brazil in the state of Mato Grosso. Blood samples were collected using EDTA (Ethylenediamine Tetraacetic Acid) during clinical procedures for hematologic, molecular and serological analyses. The samples were collected following the Ethical Guidelines for Animal Research established by the Brazilian Society of Laboratory Animal Science (SBCAL) and approved by the university's Animal Research Ethics Committee (Protocol No. UFMT 23108.017751/11-7).

\section{Hematological analysis}

The hematological analysis was based on the following reference parameters adopted by the Clinical Pathology Laboratory of the
Veterinary Hospital: erythrocytes $5.5-10 \times 10^{6} / \mathrm{mm}^{3}$; hemoglobin 08-14 g/dl; hematocrit 24-45\%; mean corpuscular volume (MCV) 37-49 $\mu^{3}$; mean corpuscular hemoglobin concentration (MCHC) $30-36 \mathrm{~g} / \mathrm{dl}$; total leukocyte count $6-19 \times 10^{3} / \mathrm{mm}^{3}$; neutrophils $2.8-17.5 \times 10^{3} / \mathrm{mm}^{3}$; eosinophils $0.0-1.3 \times 10^{3} / \mathrm{mm}^{3}$; lymphocytes $1.3-13.7 \times 10^{3} / \mathrm{mm}^{3}$; monocytes $0.0-1.3 \times 10^{3} / \mathrm{mm}^{3}$; platelets $180-400 \times 10^{3} / \mathrm{mm}^{3}$; and total protein $6-8 \mathrm{~g} / \mathrm{dl}$.

\section{Nucleic acid extraction and PCR}

Blood samples were subjected to a DNA extraction using an AxyPrep Blood Genomic DNA Miniprep Kit (Axygen Biosciences, China). The DNA was then used as template for two PCR assays designed to partially amplify the $d s b$ and 16S rRNA genes of Ehrlichia.

Amplification of the $d s b$ gene was performed with the primers dsb-330 (5'- GAT GAT GTC TGA AGA TAT GAA ACA AAT $\left.-3^{\prime}\right)$ and dsb-728 (5'- CTG CTC GTC TAT TTT ACT TCT TAA AGT -3'), designed to amplify $409 \mathrm{bp}$, adapted from Doyle et al. (2005), at an annealing temperature of $58^{\circ} \mathrm{C}$. The $16 \mathrm{~S}$ rRNA gene was amplified by two-step PCR with the primers ECC (5'- AGA ACG AAC GCT GGC GGC AAG CC -3') and ECB (5'- CGT ATT ACC GCG GCT GCT GGC-3') in the first reaction at an annealing temperature of $65^{\circ} \mathrm{C}$, yielding an amplicon of $458 \mathrm{pb}$, and with the primers ECAN (5'- CAA TTA TTT ATA GCC TCT GGC TAT AGGA -3') and HE3 (5'-TAT AGG TAC CGT CAT TAT CTT CCC TAT - 3 ') in the second reaction at an annealing temperature of $55^{\circ} \mathrm{C}$, yielding an amplicon of $398 \mathrm{pb}$ (OLIVEIRA et al., 2009). A PCR negative control (ultrapure - MilliQ ${ }^{\circ}$ ) and positive control (DNA from the São Paulo strain of E. canis obtained from DH82 culture) were used in each reaction. The PCR products were subjected to electrophoresis with $1.5 \%$ agarose gel, stained with GelRed ${ }^{\text {TM }}$ Nucleic Acid Gel Stain, 10,000X in Water- Biotium, and examined under an UV transilluminator.

\section{Purification and genetic sequencing}

Conventional $d s b$ PCR products were purified using an Illustra GFX PCR DNA and Gel Band Purification Kit (GE Healthcare Bio-Sciences, USA) according to the manufacturer's instructions, and were sequenced directly using the primers dsb- 330 and dsb728 and a Big Dye Kit (Applied Biosystems, USA), according to the manufacturer's instructions in an ABI-PRISM 3100 Genetic Analyzer. The sequences were edited using SeqMan software (Lasergene, DNAstar, USA.), and similarity was analyzed using the Basic Local Alignment Search Tool (BLAST) (ALTSCHUL et al., 1990) to check for homology with corresponding sequences available in the GenBank database.

\section{Indirect fluorescence assay}

The presence of anti-Ehrlichia spp. antibodies was evaluated by IFA, using the São Paulo strain of E. canis as antigen with a cut-off point at an initial dilution of 1:40 (AGUIRRE et al., 2004). Commercial fluorescein isothiocyanate-conjugated anti-cat 
IgG (Sigma-Aldrich, USA) was used as conjugate at a dilution of 1:1,000. The antigen preparation and IFA technique were performed as previously described (AGUIAR et al., 2007) and both positive and negative control sera were included in each assay.

\section{Statistical analysis}

Data were collected from medical records of cats to evaluate possible associations with the presence of ehrlichial DNA or antibodies against Ehrlichia spp. Anamnestic data (age, sex, and history of tick infestation) and hematological alterations were evaluated. To define age, cats with a body mass of less than $1.5 \mathrm{~kg}$ were considered young, while cats weighing $\geq 1.5 \mathrm{~kg}$ were considered adults, based on their dental arcade, according to the study of Sharif et al. (2007). To better evaluate the IFA results, the samples were grouped according to serological titers: Titers between 1:40 and 1:640 (Group A) and titers between 1:1,280 and 1:40,960 (Group B). All the data were evaluated by the Chi-square test $\left(\chi^{2}\right)$ or Fisher's exact test when applicable. Variables that presented $\mathrm{p} \leq 0.05$ were considered significant. The statistical software EPIINFO 3.5.3 (CDC, 2013) was used for this analysis.

\section{Results}

Thirty-eight (40.9\%) of the 93 cats were females and 55 (59.1\%) were males. Nineteen (20.4\%) were young and 68 (73.1\%) were adults. Age data for six cats were not available. Table 1 describes the hematological changes observed in the cats, none of which had ticks.

Eight $(8.6 \%)$ of the cats were found to have ehrlichial DNA, according to PCR targeted portions of the ehrlichial $d s b$ and $16 S$ rRNA genes. Partial DNA sequences (350 bp) of all $d s b$
PCR-positive samples were generated, yielding a sequence that is identical to multiple corresponding $E$. canis sequences in the GenBank database (GU586135.1, DQ460716.1, DQ460715.1, CP000107.1). Six of the positive cats (75\%) were adults and two $(25 \%)$ were young $(\mathrm{p}>0.05)$. PCR-positivity was distributed equally $(50 \%)$ between males and females ( $p>0.05)$. Hematological changes such as thrombocytopenia and lymphopenia were observed in several positive cats, but no significant association between positivity and thrombocytopenia was detected. On the other hand, PCR-positive cats showed a tendency to be lymphopenic ( $p=0.07$; Table 1). No other association was observed between hematological parameters and PCR positivity.

The IFA indicated that $42(45.1 \%)$ cats were positive. Ten positive cats $(23.8 \%)$ were young and $29(69.0 \%)$ were adults ( $p>0.05)$. Age data of three cats were not available. Twenty-two positive cats $(52.4 \%)$ were males and $20(47.6 \%)$ were females ( $p>0.05)$. Antibody titers ranged from 40 to 40,960 (Table 2).

Thrombocytopenia, lymphopenia, and monocytosis were observed in seropositive animals, although no association was found (Table 1). Cats showing IgG antibody titers between 40 and 640 against ehrlichial antigens were associated with low erythrocyte counts $(\mathrm{p}=0.05)$. Six PCR-positive cats $(75.0 \%)$ were seropositive, one of which presented titers of 40 , four presented titers of 160 and one presented a titer of 40,960 .

\section{Discussion}

In Brazil, feline ehrlichiosis infection is still ignored, despite the increasing rates of infection in dogs. In the geographical area of this study, it was previously determined that the seroprevalence of CME was $42.5 \%$ (SILVA et al., 2010), which is close to the prevalence rate established in the present study for cats. On the

Table 1. Association between hematological findings with positive results in PCR and IFA for Ehrlichia spp. from cats treated at the Federal University of Mato Grosso Veterinary Hospital in Cuiabá, Brazil.

\begin{tabular}{|c|c|c|c|c|c|c|c|c|}
\hline \multirow{2}{*}{$\begin{array}{c}\text { Clinical and laboratory } \\
\text { abnormalities }\end{array}$} & \multicolumn{4}{|c|}{ PCR } & \multicolumn{4}{|c|}{ IFA } \\
\hline & $n$ & Positive & $\%$ & p-value & $n$ & Positive & $\%$ & p-value \\
\hline \multicolumn{9}{|l|}{ Erythrocytes } \\
\hline$<5.5 \times 10^{6} / \mathrm{mm}^{3}$ & 20 & 2 & 10.0 & 0.54 & 20 & 9 & 45.0 & 0.59 \\
\hline $5.5-10 \times 10^{6} / \mathrm{mm}^{3}$ & 73 & 6 & 8.2 & & 73 & 33 & 45.2 & \\
\hline$>10 \times 10^{6} / \mathrm{mm}^{3}$ & 0 & 0 & 0 & & 0 & 0 & 0 & \\
\hline \multicolumn{9}{|l|}{ Leukocytes } \\
\hline$<5.5 \times 10^{3} / \mathrm{mm}^{3}$ & 7 & 0 & 0 & 0.67 & 25 & 7.0 & 28.0 & 0.11 \\
\hline $5.5-19.5 \times 10^{3} / \mathrm{mm}^{3}$ & 55 & 6 & 9.8 & & 61 & 32 & 52.5 & \\
\hline$>19.5 \times 10^{3} / \mathrm{mm}^{3}$ & 23 & 2 & 8.0 & & 7.0 & 3.0 & 16.7 & \\
\hline \multicolumn{9}{|l|}{ Monocytes } \\
\hline $0-0.8 \times 10^{3} / \mathrm{mm}^{3}$ & 63 & 5 & 7.9 & 0.50 & 63 & 31 & 49.2 & 0.13 \\
\hline$>0.8 \times 10^{3} / \mathrm{mm}^{3}$ & 30 & 3 & 10.0 & & 30 & 11 & 36.7 & \\
\hline \multicolumn{9}{|l|}{ Platelets } \\
\hline$<300 \times 10^{3} / \mathrm{mm}^{3}$ & 53 & 6 & 11.3 & 0.24 & 53 & 21 & 39.6 & 0.11 \\
\hline $300-800 \times 10^{3} / \mathrm{mm}^{3}$ & 40 & 2 & 5.0 & & 40 & 21 & 52.5 & \\
\hline$>800 \times 10^{3} / \mathrm{mm}^{3}$ & 0 & 0 & 0 & & 0 & 0 & 0 & \\
\hline \multicolumn{9}{|l|}{ Lymphocytes } \\
\hline$<1.1 \times 10^{3} / \mathrm{mm}^{3}$ & 31 & 5 & 16.1 & 0.07 & 31 & 12 & 48.4 & 0.19 \\
\hline $1.1-10.7 \times 10^{3} / \mathrm{mm}^{3}$ & 62 & 3 & 4.8 & & 62 & 30 & 38.7 & \\
\hline$>10.7 \times 10^{3} / \mathrm{mm}^{3}$ & 0 & 0 & 0 & & 0 & 0 & 0 & \\
\hline
\end{tabular}


Table 2. Frequency of Ehrlichia canis antibody titers obtained by IFA grouped according to serological titers (Groups A and B) in comparison with PCR results in blood samples collected from positive cats, Cuiabá, MT, Brazil.

\begin{tabular}{ccccc}
\hline Group & IFA Titers & $\boldsymbol{n}$ & $\%$ & PCR-Positive \\
\hline \multirow{4}{*}{ A } & 40 & 1 & 2.4 & 1 \\
& 80 & 6 & 14.3 & 0 \\
& 160 & 16 & 38.0 & 4 \\
& 320 & 4 & 9.5 & 0 \\
& 640 & 6 & 14.3 & 0 \\
& 1,280 & 7 & 16.7 & 0 \\
& 2,560 & 0 & 0 & 0 \\
& 5,120 & 0 & 0 & 0 \\
& 10,240 & 1 & 2.4 & 0 \\
& 20,480 & 0 & 0 & 0 \\
& 40,960 & 1 & 2.4 & 1 \\
\hline
\end{tabular}

other hand, the proportion of PCR-positive cats studied was lower than the current proportion of Ehrlichia PCR-positive dogs (33\%) diagnosed in our laboratory (personal communication, AGUIAR, D.M.). However, the rate of $8.6 \%$ of PCR-positive cats in two target genes highlights the potential infection by $E$. canis in the feline population of Cuiabá, which is a known E. canis epidemic region in Brazil (SILVA et al., 2010; ALMEIDA et al., 2012; MELO et al., 2011).

Clinical and laboratory manifestations suggestive of ehrlichiosis have been reported in cats (BREITSCHWERDT et al., 2002) and, unlike CME, little is known about the pathogenesis or immunopathological implications resulting from chronic infection in cats (SHAW et al., 2001). The PCR results revealed that positive cats have a tendency for lymphopenia $(p=0.07)$, a finding that is commonly reported in animals in the acute phase of infection (HARRUS et al., 1997). The evaluation of the positive cats indicated that most of them presented thrombocytopenia, which is consistent with the findings of Oliveira et al. (2009). However, these results were not statistically confirmed. In CME, thrombocytopenia appears as the result of megakaryocytic hypoplasia and reduced platelet life span, the latter occurring through immune-mediated inflammatory alteration and/or disruption of the coagulation mechanisms (HARRUS et al., 1996a, b). Other factors that may cause thrombocytopenia in cats, such as autoimmune diseases, metastatic or hematologic malignancies, infectious diseases (FeLV and FIV) and protozoan infections (Leishmaniasis and Babesiasis), must be considered as differential diagnoses of feline ehrlichiosis.

Cats that were IFA positive did not show an association with low erythrocyte count. Nevertheless, evaluating these variables according to different titer values, cats with titers ranging from 40 to $640(n=33)$ showed an association with low erythrocyte count. Among them, five cats that presented low titers also tested positive by PCR, suggesting that these cats were in the acute phase. In the acute phase of ehrlichiosis, anemia is associated with suppression of erythrocyte production and accelerated destruction of these cells. On the other hand, in the chronic phase of infection, anemia occurs due to bone marrow hypoplasia (HARRUS et al., 1999).

No association was found between age and sex. These results are similar to those reported by Stubbs et al. (2000) regarding age, although those authors found gender predominance with higher female positivity. According to our results, Ehrlichia infection is distributed equally in terms of age and sex, highlighting the widespread dissemination of the infection in the feline population treated at the Federal University of Mato Grosso Veterinary Hospital.

It is unknown if the response to feline infection shows the same characteristics as that of canine ehrlichiosis. Therefore, further investigations into the dynamics of Ehrlichia infection may shed further light on the pathogenesis of ehrlichial agents in felines.

\section{Acknowledgements}

This work was financed by the Brazilian research funding agencies FAPEMAT (Research Support Foundation of the State of Mato Grosso) and CNPq (National Council for Scientific and Technological Development). The authors gratefully acknowledge the scholarships granted by CAPES (Federal Agency for the Support and Improvement of Higher Education) to IAB, LGFS, ALTM and AFG, and by CNPq to TFZ and DMA.

\section{References}

Aguiar DM, Saito TB, Hagiwara MK, Machado RZ, Labruna MB. Diagnóstico sorológico de erliquiose canina com antígeno brasileiro de Ehrlichia canis. Cienc Rural 2007; 37(3): 796-802. http://dx.doi. org/10.1590/S0103-84782007000300030

Aguirre E, Tesouro MA, Amusategui I, Rodríguez-Franco F, Sainz A. Assessment of feline ehrlichiosis in central Spain using serology and a polymerase chain reaction technique. Ann NYAcad Sci 2004; 1026: 103105. PMid:15604476. http://dx.doi.org/10.1196/annals.1307.013

Almeida ABPF, Paula DAJ, Dahroug MAA, Freitas AG, Silva JN, Dutra V, et al. Ehrlichia canis e Anaplasma platys em carrapatos de cães de Cuiabá, Mato Grosso. Semina Cienc Agrárias 2012; 23(3): 1123-1126. http:// dx.doi.org/10.5433/1679-0359.2012v33n3p1123

Altschul SF, Gish W, Miller W, Myers EW, Lipman DJ. Basic local alignment search tool. J. Mol Biol 1990; 215(3): 403-410. http://dx.doi. org/10.1016/S0022-2836(05)80360-2

Beaufils JP, Marin-Granel J, Jumelle P. Ehrlichia infection in cats: a review of three cases. Prat Med Chir Anim Comp 1995; 30:397-402.

Bjoersdorff A, Svendenius L, Owens JH, Massung RF. Feline granulocytic ehrlichiosis: a report of a new clinical entity and characterisation of the new infectious agent. J Small Anim Pract 1999; 40(1): 20-24. PMid:10092038. http://dx.doi.org/10.1111/j.1748-5827.1999. tb03249.x

Bouloy RP, Lappin MR, Holland CH, Thrall MA, Baker D, O’Neil S. Clinical ehrlichiosis in a cat. J Am Vet Med Assoc 1994; 204(9):14751478. PMid:8050974.

Braga MSCO, André MR, Freschi CR, Teixeira MCA, Machado RZ. Molecular and serological detection of Ehrlichia spp. in cats on São Luís Island, Maranhão, Brazil. Rev Bras Parasitol Vet 2012; 21(1): 37-41. http://dx.doi.org/10.1590/S1984-29612012000100008

Breitschwerdt EB, Abrams-Ogg ACG, Lappin MR, Bienzle D, Hancock SI, Cowan SM, et al. Molecular evidence supporting Ehrlichia canis-like infection in cats. J Vet Intern Med 2002; 16(6): 642-649. PMid:12465759. 
Buoro IBJ, Atwel RB, Kiptoon JC, Ihiga MA. Feline anemia associated with Ehrlichia-like bodies in three domestic short-haired cats. Vet Rec 1989; 125(17): 434-436. PMid:2588453. http://dx.doi.org/10.1136/ vr.125.17.434

Centers for Disease Control and Prevention - CDC. Epi Info 7 [online]. 2013 [cited 2013 Jan 10]. Available from: http://wwwn.cdc. gov/epiinfo/7/index.htm

Doyle CK, Labruna MB, Breitschwerdt EB, Tang YW, Corstvet RE, Hegarty BC, et al. Detection of medically important Ehrlichia by quantitative multicolor taqman real-time polymerase chain reaction of the dsb gene. J Mol Diagn 2005; 7(4): 504-510. http://dx.doi.org/10.1016/ S1525-1578(10)60581-8

Harrus S, Aroch I, Lavy E, Bark H. Clinical manifestations of infectious canine cyclic trombocytopenia. Vet Rec 1997; 141(10): 247-250. PMid:9308149. http://dx.doi.org/10.1136/vr.141.10.247

Harrus S, Waner T, Bark H, Jongejan F, Cornelissen AWCA. Recent advances in determining the pathogenesis of canine monocytic ehrlichiosis. J Clin Microbiol 1999; 37(9): 2745-2749. PMid:10449445 PMCid:PMC85367.

Harrus S, Waner T, Eldor A, Zwang E, Bark H. Platelet dysfunction associated with experimental acute canine ehrlichiosis. Vet Rec 1996a; 139(12): 290-293. PMid:8890464. http://dx.doi. org/10.1136/vr.139.12.290

Harrus S, Waner T, Weiss DJ, Keysary A, Bark H. Kinetics of serum antiplatelet antibodies in experimental acute canine ehrlichiosis. Vet Immunol Immunopathol 1996b; 51(1-2): 13-20. http://dx.doi. org/10.1016/0165-2427(95)05516-9
Little SE. Ehrlichiosis and anaplasmosis in dogs and cats. Vet Clin North Am Small Anim Pract 2010; 40(6): 1121-1140. PMid:20933140. http:// dx.doi.org/10.1016/j.cvsm.2010.07.004

Melo ALT, Martins TF, Horta MC, Moraes-Filho J, Pacheco RC, Labruna $\mathrm{MB}$, et al. Seroprevalence and risk factors to Ehrlichia spp. and Rickettsia spp. in dogs from the Pantanal Region of Mato Grosso State, Brazil. Tick Tick Borne Dis 2011; 2(4): 213-218. PMid:22108015. http://dx.doi. org/10.1016/j.ttbdis.2011.09.007

Oliveira LS, Mourão LC, Oliveira KA, Agostini MM, Oliveira AC, Almeida MR, et al. Molecular detection of Ehrlichia canis in cats in Brazil. Clin Microbiol Infect 2009; 15(S2): 53-54. PMid:19374643. http://dx.doi.org/10.1111/j.1469-0691.2008.02175.x

Sharif M, Nasrolahei M, Ziapour SP, Gholami S, Ziaei H, Daryan $\mathrm{D}$, et al. Toxocara cati infections in stray cats in northern Iran. J Helminthol 2007; 81(1): 63-66. PMid:17381869. http://dx.doi. org/10.1017/S0022149X07214117

Shaw SE, Day MJ, Birtles RJ, Breitschwerdt EB. Tick-borne infectious diseases of dogs. Trends Parasitol 2001; 17(2): 74-80. http://dx.doi. org/10.1016/S1471-4922(00)01856-0

Silva JN, Almeida ABPF, Boa Sorte E, Freitas AG, Santos LGF, Aguiar $\mathrm{DM}$, et al. Soroprevalência de anticorpos anti-Ehrlichia canis em cáes de Cuiabá, Mato Grosso. Rev Bras Parasitol Vet 2010; 19(2): 108-111. PMid:20624348. http://dx.doi.org/10.4322/rbpv.01902008

Stubbs CJ, Holland CJ, Relf JS, Bruns C, Wheeler S, Lappin MR. Feline ehrlichiosis. Comp Cont Educ Pract 2000; 22: 307-318.

Vieira RFC, Biondo AW, Guimarães MAS, Santos AP, Dos Santos RP, Dutra LH, et al. Ehrlichiosis in Brazil. Rev Bras Parasitol Vet 2011; 20(1): 1-12. PMid:21439224. http://dx.doi.org/10.1590/ S1984-29612011000100002 